Insisiva Dental Journal, Vol. 6 No. 2 Bulan November Tahun 2017

\title{
Tata Laksana Mucous Membrane Pemphigoid (MMP) yang Dipicu Oleh Obat Herbal
}

\author{
Governance Mucous Membrane Pemphigoid (MMP) which \\ is triggered by Herbal Medicine
}

\author{
Toni Masruri ${ }^{1}$, Kus Harijanti ${ }^{2}$ \\ ${ }^{1}$ Residen Ilmu Penyakit Mulut, Fakultas Kedokteran Gigi Universitas \\ Airlangga \\ ${ }^{2}$ Staf Pengajar Ilmu Penyakit Mulut, Fakultas Kedokteran Gigi Universitas \\ Airlangga \\ Korespondensi: tomas61079@gmail.com
}

\begin{abstract}
Introduction: Mucous membrane pemphigoid (MMP) is a rare autoimmune disorder preceded with blisters various in size, commonly involving oral mucosa, conjunctiva, rarely the skin. This disorder often affects elderly female (over 50 years old) more than male. Diagnosis is very difficult to differentiate with other autoimun disorders involving mucosa, and often triggered by drugs. Purpose: This paper reports a management of MMP on an elderly javanese woman. Case: 60 year-old-woman complained of painful persistent ulsers since 3 months ago, without history of prodromal sympthoms. Clinical examination revealed multiple ulcers and eroded mucosa covered by pseudomembranes. Slight bleeding was observed. Dark brown, painful crusts were observed on lower lip. No lesion appears elsewhere. Patient admitted of consuming herbal medication. Management: several tests were ordered and patient was treated sympthomatically using antiseptic and anti-inflammatory mouthwash. Complete Blood Count $(C B C)$ showed elevated ESR, direct mycology showed yeast formation, while liver function, renal function and blood glucose level were normal. Patient was then treated with oral corticosteroids, topical antifungal, immunomodulator and antiseptic mouthwash. Recovery was achieved within one month follow-up. Conclusion: The diagnosis of MMP was established based on history, clinical appearance and examinations. Treatment requires long-term administration of oral corticosteroids, therefore good cooperation between operators and patients is necessary, as well as patient adherence to taking medication and regular controls.
\end{abstract}

Keywords: Mucous Membrane Pemphigoid (MMP), autoimmune disorder, corticosteroids.

\begin{abstract}
Abstrak
Pendahuluan: Mucous Membrane Pemphigoid (MMP) adalah suatu kelainan autoimun yang jarang terjadi. Gambaran lesinya sangat bervariasi (dengan didahului lesi berbentuk blisters) biasanya melibatkan mukosa oral dan mukosa mata. Kelainan ini sering menyerang penderita usia diatas 50 tahun. Berdasarkan gambaran klinis diagnosis penyakit ini sulit dibedakan dengan penyakit autoimun lain yang melibatkan mukosa, dan sering dipicu oleh penggunaan obat-obatan. Tujuan: Melaporkan tata laksana kasus pada penderita MMP usia 60 tahun suku Jawa Kasus: Pasien wanita, usia 60 tahun sejak 3 bulan yang lalu terdapat ulser disertai erosi di seluruh mukosa rongga mulut dan ada sedikit perdarahan, tanpa fase sembuh, terasa sakit. Ulser muncul tanpa didahului gejala prodromal. Pada bibir bawah ditemukan adanya krusta, warna coklat kehitaman, sakit dan tidak ditemukan adanya lesi di kulit dan mata. Pasien mengaku sering mengkonsumsi obat-obatan herbal. Tata Laksana: Pasien diresepkan obat kumur antiinflamasi dan
\end{abstract}


Toni Masruri, Kus Harijanti | Tata Laksana Mucous Membrane Pemphigoid (MMP) yang Dipicu Oleh Obat Herbal

antiseptik. Dan kemudian dilakukan beberapa tes penunjang. Hasil tes menunjukkan terdapat kenaikan Laju Endap Darah, pemeriksaan mikologi menunjukkan adanya yeast, fungsi hati, ginjal, dan kadar gula darah normal. Pasien dirawat dengan kortikosteroid per oral, antifungi topikal, immunomodulator, dan obat kumur antiseptik. Perawatan dilakukan selama 1 bulan. Kesimpulan: Diagnosis Mucous Membrane Pemphigoid (MMP) ditegakkan berdasarkan anamnesis, gambaran klinis, pemeriksaan ektra oral dan intra oral. Perawatan Mucous Membrane Pemphigoid (MMP) memerlukan pemberian kortikosteroid jangka panjang, oleh karena itu dibutuhkan kerjasama yang baik antara operator dan pasien, ketaatan pasien dalam minum obat serta kontrol teratur.

Kata Kunci: Mucous Membrane Pemphigoid (MMP), autoimun, kortikosteroid

\section{PENDAHULUAN}

Mucous Membrane Pemphigoid (MMP) adalah suatu kelainan autoimun kronis ditandai dengan suatu blisters/gelembung (lepuhan) yang mengenai membran mukosa. ${ }^{1,2,4}$ Mukosa yang terlibat adalah mukosa rongga mulut (80\%), konjungtiva, nasofaring, esofagus, laring, dan mukosa genital.,2,3,5,6 Gambaran lesinya bisa berupa ulser, erosi yang tertutup pseudomembran, patch kemerahan, blisters. ${ }^{5,6}$ Secara epidemiologi Mucous Membrane Pemphigoid (MMP) banyak mengenai usia dekade kelima, dan sering mengenai pada usia 60-80 tahun. Wanita dua kali lebih banyak daripada pria, anak-anak jarang terkena. Penyakit ini tidak mengenal ras dan kondisi geografis., ${ }^{1,2,7,8}$ Nama lain dari MMP adalah Benign Mucous Membrane Pemphigoid, Cicatricial Pemphigoid, dan Ocular or Oral-

\section{Gingival Pemphigoid. ${ }^{3}$}

Penegakan diagnosis dari penyakit ini adalah dengan melihat gambaran klinis, pemeriksaan ekstra oral dan intra oral, serta dengan pemeriksaan penunjang berupa biopsi dan direct imunofluoresence. Diagnosis banding dari penyakit ini adalah pemphigus vulgaris, bullous pemphigoid, oral lichen planus tipe erosif. ${ }^{\mathbf{1 , 6 , 7}}$

Penatalaksanaan Mucous Membrane Pemphigoid (MMP) adalah dengan menggunakan kortikosteroid topikal ataupun sistemik tergantung dari tingkat keparahan penyakit dan penggunaan obat kumur antiseptik/ antiinflamasi juga disarankan., ${ }^{\mathbf{1 , 2 , 6 , 7}}$

\section{PENATALAKSANAAN KASUS}

Pasien wanita usia 60 tahun datang ke RSGM FKG UNAIR dengan kondisi umum terlihat pucat dan kurus, mengeluhkan sariawan sejak 3 bulan yang lalu di seluruh mukosa rongga mulut, terasa sakit, dan tidak ada fase sembuh. Pasien juga mengatakan mengalami nyeri telan, dan selama sakit selalu mengkonsumsi makanan lunak. Pasien sudah berobat ke dokter umum dan dokter gigi, dan diberikan pengobatan berupa antibiotik, anti nyeri, obat kumur, oxyfresh gel, albothyl, tetapi tidak ada perbaikan sama sekali. Berat badan pasien turun 4 kilogram dalam jangka waktu 3 bulan tersebut.

Pasien mengatakan dan mengaku sering mengalami sariawan sejak usia 26 tahun, tetapi sembuh dalam waktu kurang lebih 10 hari dengan obat oles/obat tetes. Untuk sariawan yang sekarang pasien mengatakan berbeda dengan sariawan yang sudah pernah diderita sebelumnya. 2 tahun terakhir pasien mengatakan setiap hari mengkonsumsi jamu dengan campuran temulawak, kencur, kunyit, 
jahe ditambah gula sedikit atau madu, sehari satu gelas $(250 \mathrm{cc})$, jamu tersebut dibuat sendiri (alasan mengkonsumsi jamu dengan harapan menjaga kesehatan tubuh pasien).

Pemeriksaan klinis ekstra oral, kelenjar sub mandibularis kanan dan kiri palpasi teraba, lunak dan sakit. Pada sudut mulut kiri terdapat pseudomembran, warna putih kekuningan, batas jelas, tepi ireguler, sakit. Pada labial superior dan inferior kiri, terdapat krusta, multipel, warna kuning kehitaman, sakit, diameter $2 \mathrm{~cm}$ x $2 \mathrm{~mm}$. Pada pemeriksaan intra oral, pada mukosa labial kiri atas dan bawah terdapat pseudomembran, multipel, warna putih kekuningan, tepi ireguler, batas difus, sakit, ukuran $2 \mathrm{~cm}$ x $3 \mathrm{~mm}$, berdarah. Pada mukosa pipi kanan terdapat pseudomembran, multipel, warna putih kekuningan, tepi ireguler, batas difus, ukuran 4 mm x 4 mm, sakit. Pada mukosa pipi kiri terdapat pseudomembran, multipel, warna putih kekuningan, tepi ireguler, batas difus, ukuran $4 \mathrm{~mm}$ x $1 \mathrm{~cm}$, sakit.

Pada ventral lidah sebelah kiri terdapat pseudomembran, multipel, warna putih kekuningan, tepi ireguler, batas difus, ukuran $2 \mathrm{~cm} \times 1 \mathrm{~cm}$, sakit. Pada dorsal lidah terdapat lapisan putih $2 / 3$ posterior lidah, dapat dikerok, dan tidak sakit. Pada palatum posterior terdapat berbagai lesi (pseudomembran, ulser, erosi), tepi ireguler, batas difus, ukuran bervariasi, sakit.

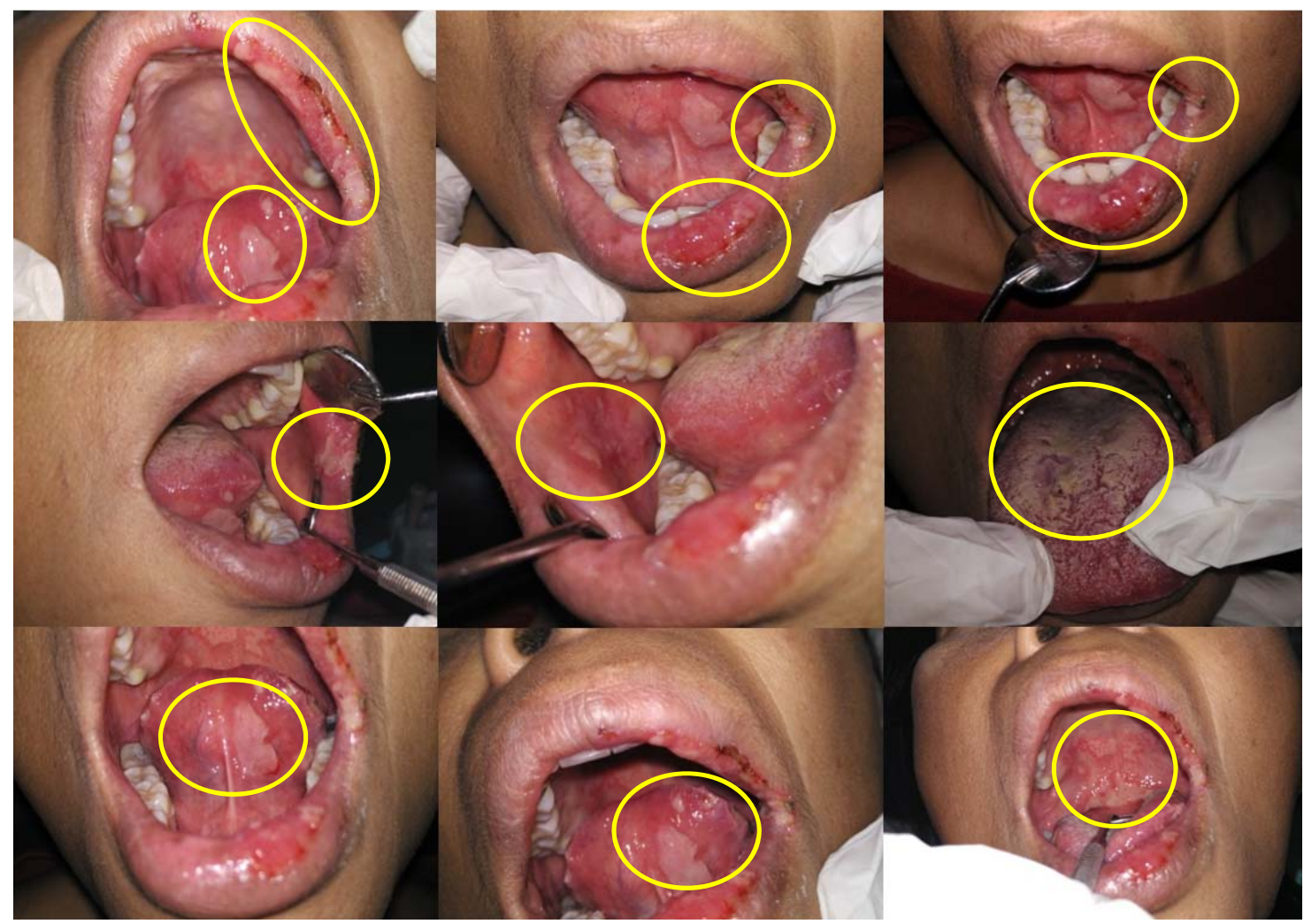

Gambar 1. Kondisi Klinis pada kunjungan pertama

Terdapat pseudomembran, di seluruh mukosa rongga mulut. Krusta kuning kehitaman di labial, berdarah dan sakit 
Toni Masruri, Kus Harijanti | Tata Laksana Mucous Membrane Pemphigoid (MMP) yang Dipicu Oleh Obat Herbal

Diagnosis klinis pasien adalah $M M P$ dengan diagnosis banding Pemphigus Vulgaris. Pada pemeriksaan darah lengkap, faal hati (SGOT/ SGPT), faal ginjal (BUN/Creatinin), dan kadar glukosa darah didapatkan terdapat peningkatan Laju Endah Darah (LED) 50-90 mm/jam dari nilai normal $12 \mathrm{~mm} / \mathrm{jam}$. Pemeriksaan jamur dilakukan pada dorsal lidah dengan metode $\mathrm{KOH}$ didapatkan adanya yeast cell, dan pada kultur jamur dengan Saboroud Dextra Agar (SDA) ditemukan Candida glabrata.

Untuk kasus ini pasien diberikan kortikosteroid (methyl prednisolone) dengan dosis awal $40 \mathrm{mg} / \mathrm{hari}$ dan selama pengobatan dilakukan tappering off dose. Diberikan azathioprine sebagai adjuvant/ immunomodulator dan obat kumur yang mengandung antiinflamasi, analgetik \& antiseptik. Selama proses pengobatan pasien diberikan multivitamin dan mineral terutama yang mengandung zinc, antijamur (nystatin oral drop), hepatoprotector, sesuai dengan kebutuhan dan kondisi perkembangan penyakit.

Pasien dilakukan kontrol setiap minggu, untuk memantau perkembangan penyakit, dan diberikan tapering off dose kortikosteroid tidak lebih dari 12,5 mg dari dosis awal.. Pada hari ke-35 pasien datang mengatakan kondisinya sudah sehat dan bugar. Sariawan di rongga mulut sudah sembuh total, hanya bekas sariawan sekarang terasa tebal dan tidak terasa sakit . Obat digunakan secara teratur.

Pengobatan kortikosteroid dilanjutkan dengan dosis maintenance sampai dengan 3 bulan.

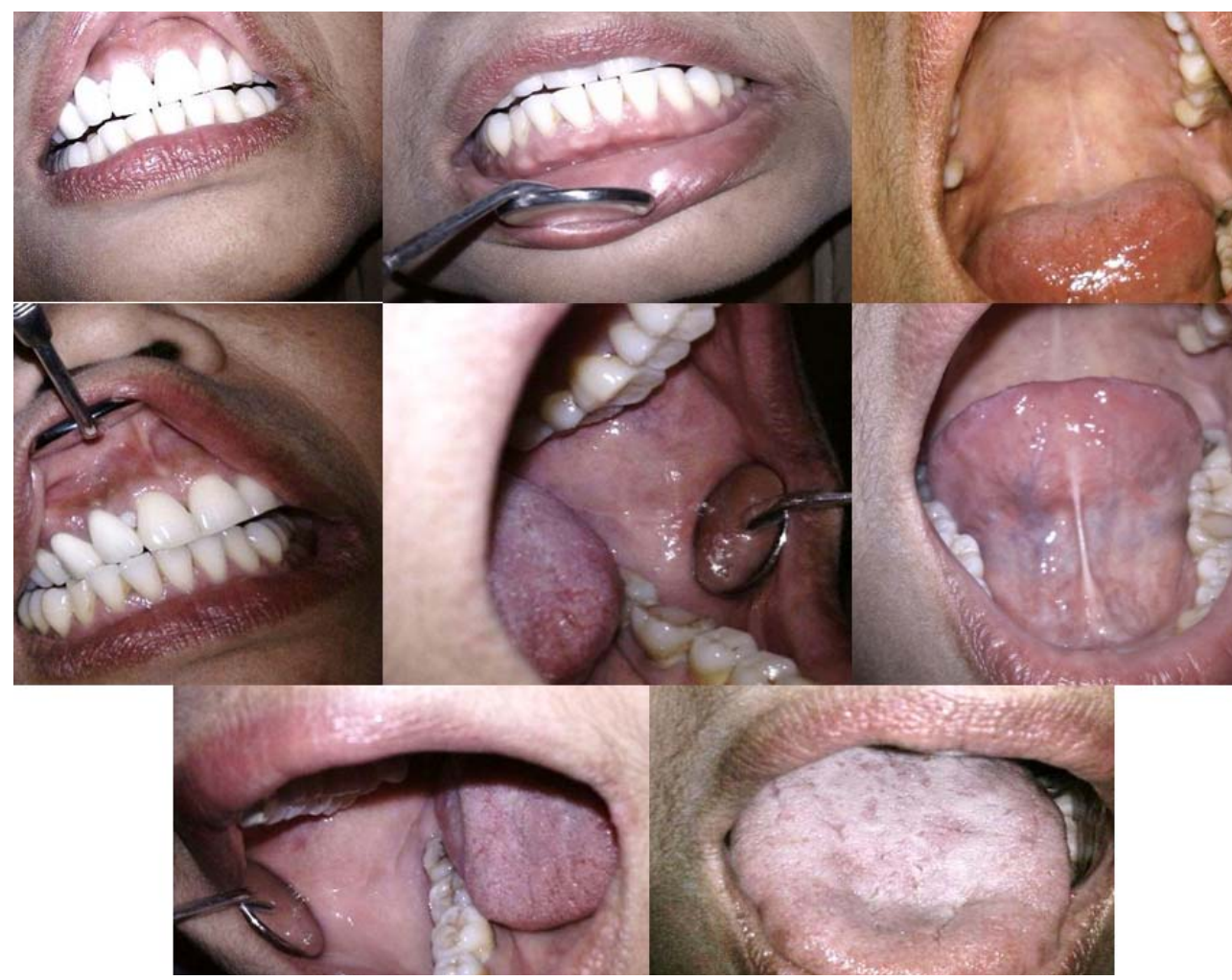

Gambar 2. Kondisi Klinis pada hari ke-35 


\section{PEMBAHASAN}

Pasien wanita usia 60 tahun datang ke RSGM FKG UNAIR dengan kondisi umum pasien terlihat pucat dan mengeluhkan sariawan sejak 3 bulan yang lalu di seluruh mukosa rongga mulut, terasa sakit, dan tidak ada fase sembuh. Pasien juga mengatakan mengalami nyeri telan, dan selama sakit selalu konsumsi makanan lunak. Pasien sudah berobat ke dokter umum dan dokter gigi, dan diberikan pengobatan berupa antibiotik, anti nyeri, obat kumur, oxyfresh oral gel, albothyl, tetapi tidak ada perbaikan, dan sariawan masih ada. Berat badan pasien turun 4 kilogram dalam jangka waktu 3 bulan tersebut.

Diagnosis klinis kondisi ini adalah Mucous Membrane Pemphigoid (MMP) berdasarkan anmnesis dan gambaran klinis, dengan diagnosis banding Pemphigus Vulgaris (PV). PV adalah suatu kelainan autoimun mukokutaneus yang dikarakteristikan dengan suatu pembentukan blisters intraepithelial, ${ }^{6}$ sehingga secara klinis memiliki gambaran yang sama dengan MMP. Seharusnya penegakan diagnosis ditunjang dengan pemeriksaan HPA (Histo Patology Anatomy) dan DIF (Direct Immuno Fluoresence), ${ }^{1,2,6,7,8}$ tetapi ada beberapa kondisi yang tidak memungkinkan untuk dilakukan biopsi apabila pasien menolak, lokasi lesi dekat dengan daerah vaskular, lokasi lesi pada daerah yang memerlukan estetik (vermillion border), akses yang sulit (ventral lidah). ${ }^{9,10}$ Pada kasus ini pasien menolak untuk dilakukan biopsi.

Pemeriksaan darah pada kunjungan pertama dimaksudkan untuk melihat kondisi sistemik pasien, fungsi hati, fungsi ginjal, kadar glukosa darah sehingga memudahkan operator untuk memberikan obat. Dari pemeriksaan darah didapatkan hasil yang normal kecuali LED yang meningkat (50-90 mm/jam), yang menunjukkan bahwa adanya infeksi akut, infeksi kronis, atau penyakit autoimun. ${ }^{11}$ Pemberian obat pada kunjungan pertama berupa analgetik dan antiinflamasi yaitu obat kumur Aloe vera extract, dengan harapan dapat memberikan rasa nyaman dan mengurangi rasa sakit karena obat ini dapat membuat barrier pada permukaan lesi sehingga melindungi lesi dari paparan atau kontak bahan lain dengan saraf tepi pada lesi, selain itu asam hialuronat dan aloe vera pada obat ini berfungsi sebagai bahan untuk mendukung proses penyembuhan pada kerusakan jaringan mukosa rongga mulut ${ }^{12,13}$.

Pemberian kombinasi multivitamin dan mineral (Vit E $30 \mathrm{iu}$, vit C $750 \mathrm{mg}$, vit B1 15 $\mathrm{mg}$, vit B2 $15 \mathrm{mg}$, vit B620 mg, vit B12 $12 \mathrm{mcg}$, folic acid $400 \mathrm{mcg}$, pantothenic acid $20 \mathrm{mg}, \mathrm{Zn}$ $22.5 \mathrm{mg}$, niacin $100 \mathrm{mg}$ ) bentuk kaplet ${ }^{14}$, adapun fungsi dari masing-masing multivitamin dan mineral ini adalah vitamin $\mathrm{E}$ dan $\mathrm{C}$ berfungsi sebagai antioksidan, dan perbaikan sistem imun, mempercepat penyembuhan luka, pembentukan jaringan ikat., vitamin B1 (Tiamin ), vitamin B2 (riboflavin), niacin berfungsi metabolisme karbohidrat, vitamin B6 (piridoksin) berfungsi untuk metabolisme protein dan glikogen., vitamin B12 (cobalamin) dan asam folat berfungsi untuk pembentukan sel darah merah, dan sintesis DNA, asam pantotenat berfungsi untuk sistesis lemak., zinc berfungsi untuk regenerasi sel, metabolisme karbohidrat, membantu mempercepat regenerasi jaringan yang rusak, meningkatkan proses penyembuhan luka. ${ }^{14,15,16}$

Pada kunjungan kedua (hari ketujuh) dan seterusnya setiap kontrol dengan tapering off 
Toni Masruri, Kus Harijanti | Tata Laksana Mucous Membrane Pemphigoid (MMP) yang Dipicu Oleh Obat Herbal

dose pasien diberikan resep methyl prednisolone. Methyl Prednisolone adalah kortikosteroid yang bersifat intermediate acting (biologic half life 12-36 jam), memiliki retensi natrium yang rendah $(0,5)$. Kortikosteroid memiliki efek antiinflamasi dan imunosupresi. ${ }^{17}$ Pada MMP terjadi peningkatan respon imun tubuh terhadap autoantigen dan radang/inflamasi di mukosa rongga mulut, sehingga dibutuhkan kortikosteroid untuk menekan reaksi tersebut. Tapering off dose dilakukan karena kondisi rongga mulut pasien sudah membaik dan untuk mencegah penekanan sistem imun yang berlebihan. Pasien juga diresepkan povidone iodine $1 \%$ obat kumur, sebagai antiseptik terhadap bakteri rongga mulut yang mungkin akan menginfeksi melalui ulser di rongga mulut yang mengganggu proses kesembuhan. ${ }^{14}$

Pada kunjungan selanjutnya pemberian ekstrak sylibum marianum dan ekstrak curcuma (hepatoprotektor) berfungsi untuk pencegahan dan perawatan liver/hati karena kerja berat liver untuk detoksifikasi obatobatan yang digunakan. ${ }^{14}$ Pasien juga diberikan obat antijamur nystatin oral drop, karena pada hasil pemeriksaan mikologi ditemukan gambaran yeast dari Candida glabrata pada lidah pasien. $C$ glabrata adalah flora normal jamur dengan jumlah sedikit pada mukosa dan kulit, dan merupakan jamur yang tidak bisa membentuk hiphae dan pseudohyphae diantara jenis Candida yang lain. ${ }^{18}$ Nistatin merupakan antijamur yang bekerja lokal, tidak diabsorpsi sistemik. Nistatin bekerja dengan mengikat ergosterol yang merupakan komponen utama dinding sel jamur. Nistatin oral drop menjadi pilihan alternatif utama sebagai pengobatan infeksi jamur karena sifat yang dimiliki yaitu bereaksi lokal dan tidak diabsorpsi (sistemik), murah, mudah diberikan, dan aman. ${ }^{19}$ Pasien juga diberikan Azathioprine tablet $50 \mathrm{mg}$ diminum sehari sekali, pemberian obat ini digunakan untuk sebagai adjuvant dan immunomodulator pada pemberian kortikosteroid. Efek samping dari pemberian kortikosteroid jangka panjang salah satunya dapat menyebabkan hiperglikemia, oleh karena itu harus selalu diperiksa kadar glukosa darah secara berkala. ${ }^{1}$

Etiologi dari penyakit ini tidak diketahui secara pasti, tetapi diduga merupakan reaksi autoimun yang dipicu oleh penggunaan obat-obatan. ${ }^{1,20}$ Patogenesis dari penyakit MMP sangat kompleks. Sirkulasi IgG dan IgA autoantibodi pada serum pasien MMP menunjukkan bahwa penyakit ini dimediasi oleh respon imun humoral. Penyakit ini terjadi ketika antibodi menyerang satu atau lebih autoantigen di subepitel dan membrana basalis. Dengan menggunakan teknik immunoblotting dan immunopresipitasi didapatkan autoantigen pada penyakit ini, yaitu bullous pemphigoid antigen 1 (BPAg 1/BP 230), bullous pemphigoid antigen 2 (BPAg 2/BP 180), integrin subunit $\alpha 6 / \beta 4$, laminin-332 (biasa disebut epiligrin dan laminin-5), laminin-6, dan kolagen tipe1. BPAg 1 adalah protein pada intraseluler, sedangkan BPAg 2 dan integrin subunit $\alpha 6 / \beta 4$ adalah protein transmembran. Bula (blister) yang terbentuk pada MMP diduga oleh induksi BPAg 2 melalui mekanisme proses inflamasi. Interaksi imunologi yang terjadi akan menyebabkan migrasi limfosit, eosinofil, neutofil, dan mast cell ke area BMZ.1,19,21

Pada pengakuan pasien, jamu yang diminum setiap hari adalah campuran temulawak 
(Curcuma xanthorrhiza Roxb), jahe (Zingiber officinale Rosc), kencur (Kaempferia galanga L), kunyit (Curcuma domestica Rhizoma) merupakan family dari jenis tanaman herbal Zingiberaceae. Interaksi kimia tanaman herbal ini tidak diketahui secara pasti, namun beberapa ahli meyakini reaksi kimianya hampir mirip dengan obat-obatan kimia, dan jenis tanaman herbal ini pernah dilaporkan menyebabkan reaksi alergi di kulit. ${ }^{22}$ Mekanisme reaksi obat dari tanaman herbal menjadi pemicu terjadinya MMP belum diketahui secara pasti, namun beberapa teori menyatakan bahwa reaksi terjadi ketika obat herbal ini menjadi hapten dan terikat dengan protein di lamina lucida, kemudian merubah sifat dan materi pada protein tersebut, sehingga hal ini memicu respon autoantibodi untuk terjadinya reaksi autoimun. ${ }^{23}$

\section{KESIMPULAN}

Dalam kasus diatas diagnosis Mucous Membrane Pemphigoid (MMP) ditegakkan berdasarkan anamnesis dan gambaran klinis, karena pasien menolak dilakukan biopsi. Perawatan Mucous Membrane Pemphigoid (MMP) memerlukan pemberian kortikosteroid jangka panjang, oleh karena itu dibutuhkan kerjasama yang baik antara operator dan pasien, ketaatan pasien dalam minum obat serta kontrol teratur. Kemungkinan relaps akan terjadi, oleh karena itu harus dievaluasi setelah 3 bulan, 6 bulan, 12 bulan dan 18 bulan.

\section{DAFTAR PUSTAKA}

1. $\mathrm{Xu} \mathrm{H}$, Werth $\mathrm{V}$, Parisi E, Sollecito T. Mucous Membrane Pemphigoid. Dent Clin North Am. 2013;57(4):611-630.

2. Glick M. Burket's Oral Medicine. 12th ed. Connecticut (USA): People's Medical Publishing House; 2015; 4:83-86

3. Pattipati S, Patil R. Mucous Membrane Pemphigoid - A Case report. Journal of Research and Advancement in Dentistry. 2012;1(3):145-150.

4. Demathé A, Arede L, Miyahara G. Mucous membrane pemphigoid in HIV patient: a case report. Cases J. 2008;1(1):345.

5. Laureano A, Cardoso J. Unilateral Oral Mucous Membrane Pemphigoid: Refractory Atypical Presentation Successfully Treated with Intravenous Immunoglobulins. Case Reports in Dermatological Medicine. 2015;2015:1-3.

6. Regezi J, Sciubba J, Jordan R. Oral Pathology. 6th ed. St. Louis, Mo.: Elsevier/ Saunders. 2012: 15-17

7. DeLong L, Burkhart N. General and Oral Pathology for The Dental Hygienist. 2nd ed. Baltimore, MD: Lippincott Williams \& Wilkins; 2013; 32-321.

8. Scully C. Oral and Maxillofacial Medicine. 3rd ed. Edinburgh: Churchill Livingstone/ Elsevier; 2013; 302-308.

9. Avon S, Klieb H. Oral Soft-Tissue Biopsy: An Overview. J Can Dent Assoc. 2012;78(c75):1-9.

10. Vidhya K, Rao P, Mukunda A. Oral biopsy: Oral pathologist's perspective. Journal of Cancer Research and Therapeutics. 2012;8(2):192-198.

11. Dirjen Kefarmasian Kemenkes RI. Pedoman Interpretasi Data Klinik. Jakarta: Kemenkes RI; 2011:24

12. Kalbemed A. Aloclair Plus. 2013 (Online), (http://www.kalbemed.com, diakses 7 April 2016) 
Toni Masruri, Kus Harijanti | Tata Laksana Mucous Membrane Pemphigoid (MMP) yang Dipicu Oleh Obat Herbal

13. Admin a. Aloclair Plus Mouthwash. 2016 (Online), (http://www.aloclairplus.co.uk, diakses pada 7 April 2016)

14. MIMS.com. 114th ed. Jakarta; 2009.

15. Institute N. Vitamin dan Mineral: Apakah Atlet Butuh Lebih? 2016 (Online), (http:// www.kalbemed.com, diakses pada 7 April 2016)

16. Haw W. Manfaat Zinc bagi Tubuh. 2014, (Online) (http://www.sehat100.com, diakses pada 13 April 2016)

17. Azis A. Penggunaan kortikosteroid di klinik (The use of corticosteroid in clinics). Jurnal Pediatri. 2014;:1-6.

18. Tam P, Gee K, Piechocinski M, Macreadie I. Candida glabrata, Friend and Foe. J.Fungi 2015,I, 277-292

19. Andriani R, Rundjan L. Nistatin Oral sebagai Terapi Profilaksis Infeksi Jamur Sistemik Pada Neonatus Kurang Bulan. Sari Pediatri. 2016;11(6):420-428.

20. Bhatia P, Dudhia B, Patel P, Patel M. Benign Mucous Membrane Pemphigoid. The Journal of Ahmedabad Dental College and Hospital. 2011;2(1):48-54.

21. Rook A, Burns T. Rook's textbook of dermatology. Chichester, West Sussex, UK: Wiley-Blackwell; 2010; 40.35-40.41

22. Aronson J. Meyler's side effects of herbal medicines. Amsterdam: Elsevier; 2009;233.

23. Kanjanabuch $\mathrm{P}$, Arporniem S, Thamrat $\mathrm{S}$, Thumasombut P. Mucous membrane pemphigoid in a patient with hypertension treated with atenolol: a case report. J Med Case Rep. 2012;6(1):373. 